\title{
PROFIL HASIL BELAJAR SISWA PADA MATERI PERBANDINGAN MELALUI PENGGUNAAN MODEL QUANTUM TEACHING DI KELAS VII SMP NEGERI 6 AMBON
}

\author{
Ferly Lewier ${ }^{1}$, Wilmintjie Mataheru ${ }^{2}$, Edith Tutuhatunewa ${ }^{3}$ \\ ${ }^{1,2,3}$ Program Studi Pendidikan Matematika Fakultas Keguruan dan Ilmu Pendidikan,Universitas Pattimura \\ Jalan Ir. M. Putuhena, Ambon, Indonesia \\ e-mail: ${ }^{1}$ ferly.lewier@gmail.com; ${ }^{2}$ wmataheru@gmail.com
}

\begin{abstract}
Abstrak
Tujuan penelitian ini, yaitu mendiskripsikan profil hasil belajar siswa pada materi perbandingan dengan menggunakan model Quantum Teaching. Jenis penelitian ini adalah Penelitian Tindakan Kelas. Subjek penelitian, yaitu siswa kelas VII $_{9}$ SMP Negeri 6 Ambon. Data penelitian ini berupa tes hasil belajar (data kuantitatif) dan lembar observasi aktivitas guru dan siswa (data kualitatif).Data kuantitatif dianalisis menggunakan statistik deskriptif, sedangkan data kualitatif dianalisis dengan cara mereduksi data, memaparkan data, dan menyimpulkan data. Penelitian ini menghasilkan profil hasil belajar siswa, yaitu pada siklus I, terdapat 7 siswa $(24,13 \%)$ tuntas dan 22 siswa $(75,87 \%)$ belum tuntas sedangkan pada siklus II, terdapat 23 siswa $(79,31 \%)$ tuntas dan 6 siswa $(20,68 \%)$ belum tuntas.
\end{abstract}

Kata Kunci: Hasil Belajar, Perbandingan, dan Quantum Teaching

\section{PROFILE OF STUDENT LEARNING OUTCOMES IN PROPOTION MATERIALS THROUGH THE QUANTUM TEACHING MODEL IN GRADE VII STUDENTS OF SMP NEGERI 6 AMBON}

\begin{abstract}
The aim of this study is to describe the profile of student learning outcomes in theproportion material using Quantum Teaching model. This type of research is Classroom Action Research. The research subjects were students of grade $\mathrm{VII}_{9}$ of SMP Negeri 6 Ambon. This research data is in the form of learning outcomes tests (quantitative data) and observation sheets of teacher and student activities (qualitative data). Quantitative data were analyzed using descriptive statistics, while qualitative data were analyzed by reducing data, describing data, and concluding data. This study produced a profile of student learning outcomes, namely in the first cycle, there were 7 students $(24.13 \%)$ completed and 22 students $(75.87 \%)$ were not completed while in the second cycle, there were 23 students $(79.31 \%)$ completed and 6 students $(20.68 \%)$ have not completed
\end{abstract}

Keywords: Learning Outcomes, Proportion, and Quantum Teaching

\section{Pendahuluan}

Berdasarkan hasil observasi peneliti pada ilmu pengetahuan yang tentunya memiliki persaingan saat ini, sangatlah diperlukan sumber daya manusia yang memiliki kemampuan intelektual dan disertai kuantitas yang dapat mengimbangi kualitas sumber daya tersebut. Kemampuan intelektual ini merupakan bagian yang tak terpisahkan dari ilmu pengetahuan. Dalam perkembangan ilmu pengetahuan dan sains itulah maka pendidikan memiliki tempat yang sangat strategis.
Miftahul (2010: 9) mengemukakan bahwa disadari atau tidak dewasa ini pendidikan di Indonesia diibaratkan seperti sebuah mobil tua yang mesinnya rewel dan sedang melintasi jalur lalu lintas di jalan bebas hambatan. Pendidikan belum berjalan secara optimal dan sangat jauh dari harapan bersama. Oleh karena itu perlu adanya sebuah terobosan baru dalam rangka pembaharuan dan modernisasi dalam pendidikan, karena tanpa pendidikan yang memadai akan sulit bagi masyarakat untuk mencapai tujuan dan keinginan menuju peradaban yang lebih maju. 
Sanjaya (2010: 1) mengungkapkan bahwa dalam proses pembelajaran siswa kurang didorong untuk mengembangkan kemampuan berpikir.Prosespembelajaran didalam kelas lebih diarahkan kepada kemampuan siswa untuk menghafal informasi, otak mereka dipaksa untuk mengingat dan menimbun berbagai informasi tanpa dituntun untuk memahami informasi yang diiingat. Akibatnya ketika mereka lulus dari sekolah mereka pintar secara teoritis akan tetapi mereka miskin aplikasi.

Proses pembelajaran yang terjadi selama ini, yaitu guru seringkali menganggap siswa sebagai wadah kosong yang diisi ilmu pengetahuan atau informasi. Guru masuk ke kelas, siswa dudukdan diam kemudian guru langsung mengajar, menyajikan pelajaran dengan metode ceramah, latihan soal dengan sedikit sekali (bahkan tanpa media pendukung) serta model pembelajaran yang digunakan masih cenderung konvensional, sehingga sangat berpengaruh terhadap hasil belajar siswa. Satu kesenjangan yang selama ini dirasakan, yaitu kurangnya pendekatan yang benar dan efektif dalam menjalankan proses pembelajaran.

Dalam proses belajar mengajar matematika selalu melibatkan siswa secara aktif untuk mengembangkan kemampuannya dalam berpikir rasional, kritis dan kreatif. Matematika yang bersifat deduktif dan abstrak, cenderung sulit diterima dan dipahami oleh siswa. Konsep matematika harus tersusun secara hirarki, artinya dalam mempelajari matematika konsep sebelumnya menjadi prasyarat yang harus benarbenar dikuasai agar dapat memahami konsep selanjutnya.

Sebelum melaksanakan penelitian ini, peneliti melakukan pendekatan dengan guru bidang studi matematika guna mencari informasi tentang masalah yang dihadapi siswa dalam proses belajar mengajar di kelas. Berdasarkan hasil tanya jawab peneliti dengan guru matematika yang mengajar di kelas VII SMP Negeri 6 Ambon ada beberapa persoalan yang timbul dalam proses pembelajaran yaitu,pada saat guru menerangkan hanya sebagian siswa saja yang memperhatikan, sementara siswa yang lain sibuk bercerita bahkan ada yang mengganggu teman, sehingga penguasaan materi oleh siswa masih tergolong lemah. Hal ini disebabkan karena model dan metode pembelajaran yang diberikan guru kurang bervariasi dan terlalu monoton, sehingga membuat interaksi belajar antara sesama siswa berkurang dan pada akhirnya motivasi belajar siswa menurun.

Materi perbandingan merupakan salah satu materi yang diajarkan pada siswa kelas VII SMP
Negeri 6 Ambon sesuai dengan Kurikulum Tingkat Satuan Pendidikan (KTSP) pada semester ganjil. Dalam materi inisiswa masih membuat kekeliruan dan kesalahan terutama dalam menentukan perbedaan perbandingan senilai dan perbandingan berbalik nilai, ketika soal cerita tersebut dibawa ke dalam konsep.Contohnya ketika siswa menyelesaikan masalahmengenai perbandingan berbalik nilai siswa menyelesaikannya dengan menggunakan cara perbandingan senilai dalam soal cerita berikut.

Lima pipa dapat mengisi sebuah tangki dalam waktu 80 menit. Berapakah waktu yang diperlukan untuk mengisi tangki tersebut jika 8 pipa yang digunakan?

Jawab:Diketahui: 5 pipa waktunya 80 menit Ditanya: Untuk 8 pipa, berapa waktu yang dibutuhkan?

Penyelesaian: misalkan yang ditanya adalah $x$, dengan menggunakan perkalian silang $5 x=80 \mathrm{x}$ $8,5 x=6400, x=\frac{6400}{5}, x=128$ menit. Ternyata jawaban siswa masih keliru. Jawaban yang benarnya adalah $\frac{x}{80}=\frac{5}{8}, 8 x=80 \times 5,8 x=400, x$ $=\frac{400}{8}, x=50$ menit. Jadi, waktu yang diperlukan 8 pipa untuk mengisi tangki adalah 50 menit. Hal ini disebabkan, guru belum mampu menyesuaikan model pembelajaran dengan materi yang diajarkan. Oleh sebab itu, diperlukan suatu model pembelajaran baru untuk memperbaiki proses pembelajaran tersebut.

Miftahul (2010: 13) berpendapat, untuk menentukan maju tidaknya sebuah pendidikan, model pembelajaran menempati posisi yang sangat penting. Penggunaan model-model pembelajaran yang tepat dalam proses pembelajaran terutama strategi pembelajaran merupakan pilar utama yang akan menentukan berhasil atau tidaknya seorang guru dalam mengajar. Salah satu model pembelajaran yang mampu mewujudkan hal tersebut adalah model Quantum Teaching,yaitu model yang menguraikan beberapa metode atau cara-cara baru yang akan lebih memudahkan kita dalam melakukan proses belajar mengajar lewat pemaduan seni dan pencapaian-pencapaian yang terarah.

Quantum Teaching merangkaikan yang paling baik dari yang terbaik menjadi sebuah paket multisensori, multi kecerdasan yang kompatibel dengan otak yang pada akhirnya akan meningkatkan kemampuan guru untuk dapat merangsang anak untuk berprestasi. Cara ini dapat memaksimalkan usaha pengajaran guru melalui perkembangan hubungan, pengubahan belajar, dan penyampaian kurikulum serta menciptakan lingkungan belajar yang efektif, menyampaikan 
isi dan memudahkan proses belajar. Quantum Teaching menawarkan ide baru tentang bagaimana menciptakan lingkungan yang jauh lebih baik serta yang menjanjikan bagi pelajar dan mendukung mereka dalam proses pembelajaran.

Groenendal (Miftahul 2010: 21) mengungkapkan, Quantum Teaching merupakan model pembelajaran yang membuat siswa merasa nyaman dan gembira dalam belajar dengan adanya kesempatan bagi siswa untuk menunjukkan kemampuannya, akan memudahkan guru dalam mengontrol sejauh mana pemerolehan siswa dalam belajar yang pada gilirannya akan dapat meningkatkan hasil belajar siswa secara signifikan. Tujuannya adalah untuk mengajari guru bagaimana orang belajar dan mengapa siswa bertindak serta bereaksi terhadap sesuatu yang selama ini terjadi. Siswa dan guru berlatih serta bekerja sebagai pemain tim guna mencapai kesuksesan bersama. Dalam konteks ini sukses guru adalah sukses siswa dan sukses siswa adalah sukses guru. Asas dari Quantum Teaching adalah ''Bawalah Dunia Mereka ke Dunia Kita', dan ' 'Antarkan Dunia Kita ke Dunia Mereka.', Dalam arti, apa yang ada dalam diri harus mampu membawa siswa untuk memahami dan mencoba menerapkan dalam kehidupan.

Berdasarkan uraian tersebut, maka peneliti tertarik untuk melakukan suatu penelitian dengan judul profil hasil belajar siswa kelas VII SMP Negeri 6 Ambon pada materi perbandingan dengan menggunakan model Quantum Teaching

\section{Metode Penelitian}

Jenis penelitian ini menggunakan Penelitian Tindakan Kelas (PTK) yang dilaksanakan melalui proses pengkajian berdaur siklus, setiap siklus terdiri dari 4 tahap, yaitu Perencanaan (Planning), Pelaksanaan (Acting), Pengamatan (Observing), danRefleksi (Reflecting).

Sumber data dalam penelitian ini adalah siswa kelas VII $_{9}$ SMP Negeri 6 dan guru mata pelajaran matematika pada kelas $\mathrm{VII}_{9}$. Jenis data, yaitu data kuantitatif berupa hasil belajar siswa dan data kualitatif berupa lembar observasi aktivitas guru dan siswa. Subjek penelitian adalah siswa kelas $\mathrm{VII}_{9}$ SMP Negeri 6 Ambon sebanyak 35 siswa yang dikelompokkan menjadi 6 kelompok.

Perangkat pembelajaran dalam penelitian ini terdiri dari Rencana Pelaksanaan Pembelajaran (RPP), Bahan Ajar (BA), dan Lembar Kerja Siswa (LKS). RPP disusun dan disesuaikan dengan sintaks model Quantum Teaching. Dalam penelitian ini dibuat 4 RPP, 2 siklus dengan 1 siklus terdiri atas 2 RPP dan 2 kali pertemuan.BA yang di dalamnya terdapat LKS, dimaksud untuk mempermudah siswa dalam mempelajari materi yang diajarkan. BA dan LKS ini berupa hal-hal yang menjadi inti materi serta memuat soal latihan yang dikerjakan siswa dalam kelompok saat proses pembelajaran berlangsung. Untuk penelitian ini disusun 4 BA dan LKS sebagai berikut.BA dan LKS 01 untuk pertemuan pertama siklus I, BA dan LKS 02 untuk pertemuan kedua siklus I, BA dan LKS 03 untuk pertemuan ketiga siklus II, dan BA dan LKS 04 untuk pertemuan keempat siklus II.

Instrumen yang digunakan dalam penelitian ini, yaitu instrumen tes hasil belajar dan instrumen lembar observasi. Lembar observasi aktivitas guru mencakup aspek-aspek pengamatan kegiatan pembelajaran yang dilakukan guru berdasarkan RPP dan model Quantum Teaching. Lembar observasi aktivitas guru diisi oleh observer (guru senior), sedangkan lembar observasi aktivitas siswa terdiri dari aspek-aspek pengamatan aktivitas siswa selama mengikuti pembelajaran. Lembar observasi aktivitas siswa diisi oleh peneliti dan 3 observer (teman seangkatan).

Dalam penelitian ini digunakan beberapa teknik, yaitu tes dan observasi. Tes bertujuanuntuk mengetahui hasil belajar siswa setelah melakukan pembelajaran. Observasi dilakukan terhadap subjek yang diteliti, yaitu siswa dan guru.

Data dari hasil penelitian ini diolah dengan menggunakan analisis data kuantitatif dan analisis data kualitatif.Data kuantitatif dianalisis menggunakan statistik deskriptif, yaitu menghitung skor yang dicapai setiap siswa dalam tes secara keseluruhan dengan rumus:

$$
\text { Hasil belajar }=\frac{\text { Jumlah skor yang diperoleh }}{\text { skor total }} \times 100
$$

Selanjutnya, dari hasil belajar siswa kemudian dibandingkan dengan Kriteria Ketuntasan Minimal (KKM) yang telah ditetapkan di Sekolah Negeri 6 Ambon, yaitu 65.Menurut Suryosubroto (2002: 77), syarat suatu pembelajaran dikatakan tuntas secara individu maupun klasikal adalah seorang siswa dikatakan tuntas belajar jika siswa tersebut mencapai skor minimal enam puluh lima. Suatu kelas dikatakan tuntas jika di dalam kelas terdapat $65 \%$ dari jumlah seluruh siswa telah mencapai daya serap lebih atau sama dengan enam puluh lima. Untuk menghitung ketuntasan secara klasikal, digunakan rumus:

Ketuntasan klasikal $=\frac{\text { jumlah siswa tuntas }}{\text { jumlah siswa }} \times 100 \%$ 
Untuk menganalisis data kualitatif, digunakan tahapan reduksi data, pemaparan data, dan penyimpulan. Berdasarkan hasil reduksi data, maka data siswa yang dianalisis sebanyak 29 orang dari jumlah keseluruhan siswa 35 . Hal ini disebabkan, karena 6 siswa tidak memiliki data lengkap.Pemaparan data adalah proses menyajikan data secara terstruktur, sehingga peneliti dapat menarik kesimpulan dalam bentuk paparan naratif, tabulasi dan grafik. Penyimpulan adalah proses ketika data yang telah diperoleh pada reduksi data dan penyajian data dirangkum kemudian disimpulkan peneliti.

\section{Hasil dan Pembahasan}

\subsection{Hasil}

Pada siklus I, dilakukan perencanaan sebagai berikut. (1) Menyiapkan RPP 01, BA 01, dan LKS 01 (materi perbandingan) dan RPP 02, BA 02, dan LKS 02 (materi skala, faktor skala pembesaran dan faktor skala pengecilan pada gambar berskala) sesuai dengan sintaks model Quantum Teachingdan (2) Menyiapkan tes akhir siklus I dan menyiapkan lembar observasi aktivitas guru dan lembar observasi aktivitas siswa.

Pelaksanaan tindakan pada siklus I dilaksanakan dalam dua kali pertemuan (4 jam pelajaran). Pada pertemuan pertama, guru berusaha menumbuhkan minat siswa melalui AMBAK (Apa Manfaatnya Bagiku) ketika mempelajari materi ini. Guru membagikan BA (Bahan Ajar) dan Lembar Kerja Siswa (LKS) 01 pada setiap kelompok dan meminta siswa memahami dan mengerjakan BA dan LKS 01 tersebut.

Guru menunjuk masing-masing ketua kelompok untuk mempersentasikan hasil kerja kelompok nanti di depan kelas. Sementara berdiskusi, musik diputar sebagai pengantar siswa dalam belajar.Selesai berdiskusi, guru mempersilahkan siswa beristirahat beberapa menit sambil menonton film yang sudah disiapkan guru. Film yang berdurasi 5-6 menit tentang pendidikan. Film ini menceritakan kisah pohon apel dan seorang anak yatim piatu, makna film yang dapat dipelajari dari kisah tersebut mengajarkan para siswa untuk selalu menghormati orang tua serta tidak sombong dan angkuh ketika suatu saat kelak menjadi orang sukses.

Guru melanjutkan materi untuk pertemuan kedua, yaitu materi skala, faktor skala pembesaran dan faktor skala pengecilan pada gambar berskala. Guru berusaha menumbuhkan minat siswa melalui AMBAK (Apa Manfaatnya Bagiku) ketika mempelajari materi ini.

Guru membagikan BA 02 dan LKS 02 pada setiap kelompok dan meminta siswa dalam tiap kelompok memahami dan mendengarkan penjelasan guru. Sementara berdiskusi musik diputar sebagai pengantar bagi siswa dalam berdiskusi. Setelah siswa selesai menyelesaikan BA 02 dan LKS 02, guru mempersilahkan kelompok yang telah siap untuk mempersentasikan hasil kerja kelompoknya di depan kelas. Setelah selesai mempresentasekan hasil diskusi kelompok, guru memberikan kesempatan kepada para siswa pada kelompok lain untuk menanggapi hasil pekerjaan teman.

Akhir dari diskusi, guru mempersilahkan siswa beristirahat beberapa menit sambil menonton film. Film untuk pertemuan kedua menceritakan tentang keledai yang sombong dan manusia yang selalu bertengkar pada akhirnya mereka sepakat untuk berteman, bekerja sama dan saling percaya ketika mereka menghadapi sebuah masalah.

Selama kegiatan pelaksanaan tindakan kelas berlangsung, dilakukan observasi terhadap guru dan siswa sebagai berikut. Berdasarkan tahapan TANDUR (Tumbuhkan, Alami, Namai, Demonstrasi, Ulangi, Rayakan) guru berusaha menumbuhkan minat siswa melalui AMBAK (Apa Manfaatnya Bagiku). Namun proses belajar mengajar pada pertemuan pertama menunjukkan bahwa guru masih perlu menyesuaikan diri dengan model Quantum Teaching dan asas Quantum Teaching.

Melalui asas Quantum Teaching guru menyampaikan sebuah cerita yang berkaitan dengan kehidupuan sehari-hari. Dalam cerita yang guru sampaikan terdapat pertanyaan yang guru berikan untuk dijawab siswa. Sementara berdiskusi, guru memutarkan musik sesuai dengan kondisi keadaan kelas saat itu. Setelah kelompok selesai berdiskusi, guru mempersilahkan kelompok yang telah siap untuk mempersentasikan hasil kerja kelompoknya. Siswa diberikan kesempatan untuk mempresentasekan hasil pekerjaan mereka melalui demonstrasi di kelas.

Selesai mempersentasekan hasil diskusi kelompok, guru mempersilahkan siswa beristirahat beberapa menit sambil menonton film yang sudah disisipkan guru. Film yang berdurasi 5-6 menit bertemakan pendidikan. Akhir diskusi, guru tak lupa memberikan pujian dan hadiah bagi kelompok yang mengerjakan BA dan LKS 01 dengan benar, dan memasangkan medali bintang sebagai tanda penghargaan. 
Guru tidak dapat memberikan pengulangan dan penyimpulan materi yang telah dipelajari untuk memperkuat pemahaman siswa, karena jam pelajaran telah berakhir. Guru meminta siswa mengumpulkan BA dan LKS, kemudian guru menutup pelajaran dan mengajak siswa berdoa serta mengucapkan salam.

Pada pertemuan kedua, guru sudah dapat menyesuaikan diri dengan model Quantum Teaching serta asas Quantum Teaching. Guru cukup fasih berkomunikasi dengan siswa, dan belum sepenuhnya menarik perhatian siswa, karena guru belum terlalu antusias dan belum terlalu menampilkan rasa semangat dalam penyampaian cerita. Guru meminta siswa kembali membentuk kelompok seperti pada pertemuan pertama.

Guru membagikan BA dan LKS 02 pada setiap kelompok dan meminta siswa untuk mendengarkan penjelasan guru. Guru memberikan kesempatan kepada siswa dalam kelompok untuk berdiskusi dan bertanya mengenai soal yang belum dipahami. Sementara siswa berdiskusi guru memutar musik sebagai pengantar siswa dalam berdiskusi. Bertepatan dengan jam pelajaran selesai, guru meminta siswa mengerjakan soal yang belum selesai dikerjakan sebagai pekerjaan rumah untuk dilengkapi dan dikumpulkan pribadi pada pertemuan selanjutnya.

Guru mempersilahkan siswa beristirahat beberapa menit sambil menonton film yang sudah disisipkan guru. Film yang berdurasi 5-6 menit bertemakan tentang pendidikan. Guru memberikan pengulangan dan bersama siswa menarik kesimpulan dari materi yang dipelajari. Selanjutnya, menginformasikan untuk pertemuan selanjutnya akan diadakan tes. Oleh karena itu, guru tidak mengumpulkan BA dan LKS namun dikembalikan untuk dilengkapi dan dipelajari siswa dalam persiapan tes. Guru menutup pelajaran dengan mengajak siswa berdoa dan mengucapkan salam.Berdasarkan hasil observasi terhadap aktivitas siswa, nampak aktivitas TANDUR (Tumbuhkan, Alami, Namai, Demonstrasi, Ulangi dan Rayakan) pada siklus I pertemuan pertama dan kedua.

Selanjutnya dilakukan refleksi terhadap siklus I, yaitu pada BA dan LKS terdapat beberapa kesalahan pengetikan yang tidak diperhatikan peneliti, yaitu (1) ada soal dalam LKS yang tidak lengkap. Adapun hal-hal yang akan diperhatikan dan diperbaiki mengenai penyusunan perangkat pembelajaran adalah sebelum BA dan LKS digunakan, peneliti, guru dan para observer berupaya lebih teliti memperhatikan kembali agar tidak terjadi kesalahan pengetikan terutama untuk soal tes yang tidak lengkap; (2) model Quantum Teaching merupakan model pembelajaran yang baru bagi guru, sehingga guru belum dapat menerapkan dengan baik pelaksanaan Quantum Teaching, misalnya guru belum memotivasi siswa dalam menumbuhkan AMBAK (Apa Manfaatnya Bagiku) dan menerapkan asas Quantum Teaching, guru masih terfokus menggunakan bahasa LKS dalam menyampaikan cerita terutama dalam konsep TANDUR (Tumbuhkan dan Alami); (3)pelaksanaan kegiatan pembelajaran belum sesuai dengan RPP dan beberapa kegiatan yang tercakup pada RPP belum sempat terlaksana (belum menyimpulkan materi, karena penggunaan waktu tidak tepat); (3) pada pertemuan pertama ada siswa yang merasa bosan ketika mendengarkan cerita yang disampaikan guru bahkan dalam menumbuhkan AMBAK, karena guru tidak terlalu antusias dalam berbicara dan menampilkan semangat, serta keharmorisan bagi siswa, siswa juga masih perlu mendapatkan bimbingan guru.Meskipun demikian,aktivitas siswa dalam kelompok nampak aktif berdiskusi bahkan ada siswa yang menjelaskan kepada teman kelompoknya yang belum mengerti; dan (4) hasil belajar siswa pada siklus I, secara keseluruhan belum mencapai KKM, karena terdapat 22 siswa $(75,87 \%)$ belum tuntas dan 7 siswa $(24,13 \%)$ yang tuntas.

Berdasarkan hasil refleksi ini maka menjadi catatan untuk memperbaiki proses pembelajaran pada siklus II.Perencanaan perbaikan siklus II dilakukan berdasarkan hasil refleksi dari pelaksanaan tindakan siklus I, sehingga perlu disusun RPP yang sesuai dengan model Quantum Teaching. Berbagai kekurangan/kelemahan yang ditemui pada siklus I, diupayakan agar semaksimal mungkin dapat diatasi pada pelaksanaan tindakan siklus II. Adapun hal-hal yang menjadi perencanaan pada siklus II sebagai berikut. (1) Batasan materi yang diajarkan pada siklus II, yaitu pada pertemuan ketiga dengan materi memberikan contoh masalah sehari-hari yang merupakan perbandingan senilai dan menyelesaikan soal yang melibatkan perbandingan senilai, sedangkan untuk pertemuan keempat materi dengan materi memberikan contoh masalah sehari-hari yang merupakan perbandingan berbalik nilai dan menyelesaikan soal yang melibatkan perbandingan berbalik nilai; (2) Menyiapkan RPP 03dan RPP 04 sesuai langkah-langkah model Quantum Teaching; (3) Menyiapkan BA dan LKS 03 serta BA dan LKS 04; (4) Menyiapkan tes akhir siklus II; dan (5) Menyiapkan lembar observasi guru.

Pelaksanaan pembelajaran pada siklus II ini dilaksanakan dalam dua kali pertemuan (4 jam 
pelajaran) yang pelaksanaannya mengacu pada RPP 03 (pertemuan ketiga) dan RPP 04 (pertemuan keempat).

Mengawali pertemuan ketiga, guru mengumumkan hasil tes siklus I dan memberikan semangat kepada siswa mengenai hasil yang diperoleh mereka dan memberikan motivasi untuk tes pada pertemuan selanjutnya. Selanjutnya guru meminta siswa mengumpulkan pekerjaan rumah yang diberikan pada pertemuan kedua. Guru berusaha menumbuhkan minat siswa melalui AMBAK (Apa Manfaatnya Bagiku) ketika mempelajari materi. Guru meminta siswa kembali membentuk kelompok seperti pada pertemuan.

Guru meminta tiap kelompok siswa memahami dan mendengarkan lanjutan cerita dari pertemuan kedua. Dalam cerita yang guru berikan terdapat beberapa pertanyaan yang guru berikan untuk dijawab siswa. Kemudian guru membagikan BA dan LKS 03. Guru memberikan kesempatan kepada siswa untuk bertanya.

Selama berdiskusi, guru memutar musik sebagai pengantar berdiskusi. Selesai menyelesaikan BA dan LKS 03, guru mempersilahkan kelompok yang telah siap untuk mempersentasikan hasil kerja kelompoknya. Akhir dari diskusi ini, guru mempersilahkan siswa beristirahat beberapa menit sambil menonton film yang sudah disiapkan guru.

Film yang berdurasi 5-6 menit bertemakan tentang pendidikan menceritakan tentang kisah dua orang pria yang berlomba dan bersaing untuk menjadi orang kaya dan memperebutkan putri kepala desa sebagai isteri. Inti pesan dari film yang diputar ini adalah mengajarkan siswa bijaksana, tidak membarterkan seluruh waktu dan fisiknya demi mendapatkan kekayaan, tapi dengan kecerdasan yang ia punya, ia mencari alternatif terbaik untuk mendapatkan kekayaan tanpa harus selalu membarterkan seluruh waktu dan fisiknya.

Guru memberikan pengulangan berupa tanya jawab untuk menguatkan pemahaman siswa mengenai materi yang telah dibahas. Setelah selesai, guru meminta siswa mengumpulkan BA dan LKS 03 dan membimbing siswa bersamasama menarik kesimpulan dari pelajaran yang dipelajari. Guru memberikan pujian dan hadiah bagi kelompok yang benar dan memasangkan medali bintang sebagai tanda penghargaan, kelompok yang mendapat penghargaan adalah kelompok I, II dan IV.

Guru memberikan semangat bagi kelompok yang belum dapat mengerjakan soal dengan benar dan meminta tiap kelompok saling berjabat tangan dan mengatakan terima kasih atas kerjasama yang baik. Semua kelompok gembira atas apa yang mereka dapatkan. Guru kemudian meminta semua siswa kembali dalam kelompok, karena jam pelajaran telah berahir. Guru menutup pelajaran dengan mengajak siswa berdoa dan mengucapkan salam.

Pada pertemuan keempati, guru meminta siswa untuk mengumpulkan pekerjaan rumah yang telah diberikan sebelumpa pada pertemuan ketiga. Materi yang diberikan adalah materi perbandingan berbalik nilai.

Guru menumbuhkan minat siswa melaui AMBAK ketika mempelajari materi ini kemudian guru mengorganisasikan siswa dalam kelompok, membagikan Bahan Ajar (BA) dan Lembar Kerja Siswa (LKS) 04 pada setiap kelompok dan meminta siswa memahami serta mengerjakan BA dan LKS 04. Guru meminta siswa dalam tiap kelompok memahami dan mendengarkan lanjutan cerita dari pertemuan ketiga. Melalui cerita tersebut siswa mencari dan menjawab keingintahuan siswa lewat penamaan dari cerita yang siswa peroleh. Melalui media pembelajaran berupa tusuk gigi, guru mempraktekkan penggunaan perbandingan berbalik nilai dalam kehidupan sehari-hari. Dalam cerita yang guru berikan terdapat beberapa pertanyaan untuk dijawab siswa.

Kelompok diberikan kesempatan untuk berdiskusi, memahami dan menyelesaikan soal dalam LKS dan bertanya terkait BA dan LKS 04 yang telah didiskusikan. Selama diskusi kelompok berlangsung, guru memutar musik lirik lagu. Guru menjelaskan secara singkat perbedaan antara perbandingan senilai dengan perbandingan berbalik nilai agar tidak terjadi kekeliruan. Guru memberikan penjelasan mengenai 2 cara memecahkan masalah yang melibatkan konsep perbandingan berbalik nilai dan memberikan kesempatan kepada siswa untuk memilih cara yang paling mudah untuk menyelesaikan masalah perbandingan berbalik nilai.

Setelah selesai menyelesaikan LKS 04, guru mempersilahkan kelompok yang telah siap untuk mempersentasikan hasil kerja kelompoknya. Kemudian guru memberikan penjelasan mengenai hasil pekerjaan siswa yang dituliskan di papan tulis terkait dengan grafik. Akhir dari diskusi ini, guru mempersilahkan siswa beristirahat beberapa menit sambil menonton film yang sudah disiapkan guru. Film yang berdurasi 5-6 menit menceritakan tentang kreativitas yang ditunjukkan anak-anak usia dini yang hebat bermain alat musik. Inti pesan dari film yang diambil adalah melakukan apa yang menurut orang lain tidak mampu kita lakukan. Oleh karena itu, diperlukan ketekunan dan kerja keras dalam berusaha untuk mencapai cita-cita. 
Selesai menonton film, guru memberikan pengulangan berupa beberapa pertanyaan untuk menguatkan pemahaman siswa. Setelah siswa memberikan penjelasan, guru menyempurnakan jawaban siswa dan meminta siswa mengumpulkan BA dan LKS 04 serta membimbing siswa bersama-sama menarik kesimpulan dari pelajaran yang telah dipelajari.

Guru memberikan pujian dan hadiah bagi kelompok yang benar dan memasangkan medali bintang sebagai tanda penghargaan, kelompok yang menerima penghargaan adalah kelompok I, II dan V. Guru memberikan semangat bagi kelompok yang belum dapat mengerjakan pekerjaan dengan baik dan mengajarkan tiap kelompok saling berjabat tangan dan mengatakan terima kasih atas kerjasama yang baik. Guru juga membagikan hadiah bagi siswa yang mengumpulkan poin terbanyak ketika dalam proses belajar mengajar siswa selalu menjawab pertanyaan guru. Selanjutnya guru kemudian meminta semua siswa kembali dalam kelompok. Guru menutup pelajaran dengan mengajak siswa berdoa dan mengucapkan salam.

Selama kegiatan pelaksanaan tindakan kelas berlangsung, peneliti dan observer mengamati pula kegiatan guru dan siswa dengan menggunakan lembar observasi yang telah disiapkan. Hasil observasi dari para observer menunjukan hal-hal sebagai berikut. (1) Pada pertemuan ketiga, model Quantum Teaching yang diterapkan guru dalam proses pembelajaran sudah mulai membaik, guru tidak lagi mengandalkan siswa-siswa yang berkemampuan baik, tapi seluruh siswa diberikan kesempatan untuk aktif dalam berbicara, guru telah mampu memotivasi semangat dan antusias siswa dalam proses belajar mengajar. Guru telah dapat menunjukkan ciri-ciri seorang Quantum Teacher. Guru juga telah dapat mengelola waktu dengan baik; dan (2) pada pertemuan keempat, model Quantum Teaching yang diterapkan guru dalam proses pembelajaran sudah terlaksana dengan baik. Alokasi waktu yang dipergunakan sudah tepat. Guru sudah dapat membimbing siswa agar aktif dalam diskusi kelompok dan berani menanggapi dan bertanya. Interaksi guru dan siswa, begitupun siswa dengan siswa bekerja sama dalam kelompok begitu baik. Guru bersama-sama dengan siswa membuat kesimpulan. Kemudian mengumumkan kepada siswa untuk mempersiapkan diri dengan baik, karena pada pertemuan selanjutnya akan dilaksanakan tes akhir siklus II.

Selanjutnya hasil observasi untuk siswa, yaitu (1) Nampak keaktifan dan kerjasama siswa dalam kelompok; (2) siswa antusias dalam bekerja sama dan memberikan tanggapan ataupun pertanyaan dalam kelompok. Siswa tidak lagi merasa bosan akan cerita yang disampaikan guru, karena guru telah dapat menyesuaikan alam pikiran guru dengan alam pikiran siswa. Musik yang diputar selama berdiskusi dan film yang dinonton sangat dinikmati siswa; dan (3) Guru sudah dapat menguasai siswa, karena setelah selesai nonton, siswa masih tetap fokus terhadap materi yang disampaikan. Pada waktu guru bertanya sebagi bentuk pengulangan materi, siswa dapat menjawab pertanyaan yang guru berikan. Hal ini dibuktikan dengan terlaksananya aktivitas TANDUR dalam tiap-tiap kelompok.

Pada pertemuan keempat perilaku siswa yang tidak relevan sudah berkurang, sehingga aktivitas kelompok semakin membaik. Hal ini nampak pada saat mengerjakan LKS, ada pembagian tugas dalam kelompok. Siswa telah berani mengajukan pendapat dan memberikan tanggapan terhadap hasil kerja kelompok lain. Aktivitas TANDUR dalam tiap kelompok pada pertemuan ini sudah sangat baik. Guru mampu memahami siswa dan sudah dapat menarik perhatian seluruh siswa, sehingga siswa tidak lagi kesulitan dalam memahami materi yang dipelajari.

Berdasarkan hasil observasi pelaksanaan tindakan siklus II dan hasil pekerjaan siswa pada tes akhir siklus II, peneliti, guru dan para observer melakukan refleksi. Adapun hal-hal yang direfleksi sebagai berikut. (1) Perangkat pembelajaran yang disusun baik; (2) Guru telah menguasai asas Quantum Teaching dan menerapkan model Quantum Teaching dengan baik serta melaksanakan kegiatan belajar mengajar sesuai dengan RPP yang telah disusun. Guru telah membimbing siswa untuk menemukan dan mengkonstruksi pengetahuannya sendiri, dapat bekerja sama dengan sesama anggota kelompok dalam menyelesaikan LKS, berani bertanya, dan menanggapi hasil kerja kelompok lain; (3) Kemampuan guru dalam mengkondisikan kelas dan mengontrol masing-masing kelompok menunjukkan hasil yang memuaskan, dan (3) Siswa aktif dalam berdiskusi, berani dalam mengemukakan pendapat dan berani dalam menyampaikan pertanyaan menyangkut hal-hal yang tidak dimengerti selama proses pembelajaran. Sebagian besar kelompok telah menunjukkan kerjasama kelompok dan peran serta anggota kelompok yang baik.dan aktivitas dalam kelompok menunjukkan siswa gembira,semangat, merasa bangga dan puas akan semua yang mereka dapatkan.

Hasil tes siswa pada siklus II menunjukkan siswa yang tuntas mencapai $\mathrm{KKM} \geq 65$ sebanyak 23 orang $(79,31 \%)$ dan siswa yang belum tuntas 
mencapai $\mathrm{KKM} \leq 65$ sebanyak 6 oran $(20,68 \%)$. Dengan demikian peneliti, guru dan para observer menilai bahwa pelaksanaan tindakan perbaikan telah berhasil dilaksanakan dengan baik sehingga disepakati untuk tidak melanjutkan ke siklus selanjutnya. Penyebab 6 siswa pada siklus II belum tuntas karena ketidakseriusan siswa dalam belajar.

\subsection{Pembahasan}

Berdasarkan Hasil tes siklus I menunjukkan siswa yang tuntas mencapai KKMsebanyak 7 siswa dan siswa yang belum tuntas sebanyak 22 siswa. Ini menunjukkan bahwa hasil belajar yang diinginkan belum tercapai sesuai dengan KKM. Belum terjadinya peningkatan pada siklus I berkaitan dengan proses pembelajaran menyangkut aktivitas guru dan aktivitas siswa.

Guru belum dapat menerapkan model Quantum Teaching dengan baik dan memahami dengan baik mengenai asas Quantum Teaching. Dalam proses menumbuhkan minat dan AMBAK bagi siswa, guru terlihat kurang fasih berkomunikasi dengan siswa, hubungan guru dengan siswa belum terjalin dengan baik, sehingga terlihat motivasi dan minat siswa masih begitu rendahdalam menerima yang disampaikan guru. Padahal De Porter (2011: 122) mengatakan, asas utama Quantum Teaching terletak pada kemampuan kita untuk menjembatani jurang antara dunia kita dan dunia siswa. Hal ini akan memudahkan kita membangun jalinan, menyelesaikan bahan pelajaran lebih cepat, membuat hasil belajar lebih melekat dan memastikan terjadinya pengalihan pengetahuan. Jika kita mengerti minat, hasrat, dan pikiran siswa dan kita menyampaikan bahwa kita memahami mereka, ini berarti kita telah memasuki dunia mereka.

Ada siswa dalam kelompok yang merasa bosan karena cerita yang disampaikan guru tidak menarik perhatian siswa karena guru belum terlalu antusias dalam menampilkan semangat untuk hidup kepada siswa, sehingga penyampaian cerita yang disampaikan guru terlihat biasa.

Sewaktu musik dimainkan ada kelompok juga yang merasa terganggu dengan suara musik saat proses diskusi, namun anggota kelompok lain begitu menikmati musik yang didengar. De Porter (2011: 110)mengatakan, musik berpengaruh bagi guru dan siswa. Kita dapat menggunakan musik untuk menata suasana hati, mengubah keadaan mental siswa, dan mendukung lingkungan belajar. Film yang dinonton sangat dinikmati siswa. Penelitian (De Porter 2010: 112) menunjukkan bahwa belajar lebih mudah dan cepat jika siswa berada dalam kondisi santai dan reseptif.
Siswa dalam kelompok masih bingung dengan apa yang disampaikan guru dan masih membutuhkan petunjuk guru dalam menyelesaikan LKS. Siswa dapat berpikir untuk menyelesaikan masalah, mencari idea dan membuat keputusan. Siswa akan lebih paham karena mereka terlibat langsung dalam membina pengetahuan baru, mereka akan lebih paham dan mampu mengaplikasikan dalam semua situasi.

Guru belum dapat menyakinkan siswa dan menganggap siswa mampu karena terkesan guru lebih banyak berbicara dengan siswa-siswa yang dianggap pandai. De Porter (2011: 36) mengatakan salah satu prinsip dalam Quantum Teaching adalah prinsip "Akui setiap Usaha.' Gurujuga belum dapat mengelola waktu dengan baik sehingga beberapa kegiatan yang ada pada RPP tidak terlaksana dengan baik karena waktu belajar telah usai.

Salah satu langkah TANDUR yang tidak dapat dilaksanakan guru adalah Mengulangi materi yang telah dipelajari siswa. Umpan balik sangat penting bagi proses penguatan terhadap hasil belajar yang dicapai siswa.Kerjasama dan interaksi dalam kelompok belum begitu baik karena ada perilaku tidak relevan lainnya yang dilakukan siswa.

Kekurangan lain yang terjadi terlihat pada perangkat pembelajaran yang disusun, yaitu berupa kesalahan pengetikan BA dan LKS yang menyebabkan siswa mengalami kesulitan dalam memahami apa yang dibaca, dan ada beberapa langkah penyelesaian soal yang terlewati.Melihat kekurangan yang ada serta pelaksanaan tindakan siklus I yang belum memenuhi kriteria keberhasilan yang ditetapkan, maka peneliti memutuskan agar penelitian dilanjutkan pada siklus II dengan merancang tindakan perbaikan dengan memperhatikan kekurangan-kekurangan yang terjadi pada siklus I.

Hasil belajar siklus II menunjukkan adanya peningkatan dibandingkan dengan siklus I. Siswa yang tuntas mencapai KKM sebanyak 23 orangdan siswa belum tuntas sebanyak 6 orang. Dengan demikian pada siklus II, ketuntasan $65 \%$ siswa yang memperoleh KKM telah tercapai.Terjadinya peningkatan hasil belajar pada siklus II disebabkan, karena kekurangankekurangan yang ada pada siklus I sudah diperbaiki. Bagi siswa yang belum tuntas, guru memberikan motivasi serta semangat supaya lebih giat belajar dan berusaha untuk mencapai hasil yang baik.

Model dan langkah-langkah Quantum Teaching yang dilaksanakan guru sudah baik. Guru sudah dapat mengelola waktu, sehingga model Quantum Teaching dapat terlaksana 
dengan baik pula dan tidak melebihi waktu yang ditentukan. Guru sudah fasih berkomunikasi dengan siswa, hubungan dengan siswa terjalin dengan baik, sehingga motivasi siswa dalam menerima yang disampaikan guru begitu besar.Banyak kemajuan yang terjadi pada siklus ini baik dari guru maupun siswa.Sewaktu guru menumbuhkan AMBAK bagi siswa, siswa begitu antusias dan tertarik serta memperhatikan dengan serius materi yang disampaikan guru. Keaktifan siswa sudah nampakdan sudah bisa diajak kerjasama serta berani menyampaikan pendapatnya.

Guru sudahdapat menarik perhatian siswa, karena ekspresi keceriaan dan humoris guru menampilkan semangat kepada siswa. Wiliam Ward (Tanudjaja 2011: 74) mengungkapkan, guru yang biasa-biasa saja akan bercerita, guru yang baik akan menjelaskan, guru yang hebat akan mempraktekkan, dan guru yang luar biasa akan menginspirasi.

Siswa sudah dapat menemukan dan memahami apa yang dipelajari serta berani mengemukakan pendapat, karena guru dapat menyakinkan siswa dan menganggap semua siswa mampu. Semua siswa merasa senang diakui. Menerima pengakuan membuat siswa merasa bangga, percaya diri dan bahagia. Ketika guru bertanya siswa beramai-ramai mengancungkan jempol untuk menjawab pertanyan guru.

Musik yang dimainkan dan film yang dinonton sangat menghibur siswa. Guru bersama siswa merayakan keberhasilan yang sudah dilakukan siswa sebagai pengakuan untuk penyelesaian, partisipasi, dan pemerolehan keterampilan dan ilmu pengetahuan. Menurut De Porter (2011: 36) yang membawa kita kepada salah satu prinsip Quantum Teaching, yaitu jika layak dipelajari maka layak pula dirayakan.

Sebagai guru, kita layak menanamkan bibit kesuksesan dan selalu menghubungkan belajar dengan perayaan. Ekspresi yang ditampilkan siswa begitu luar biasa, siswa sangat gembira.Ini menunjukkan bahwa siswa sangat tertarik dan senang dengan model pembelajaran yang guru terapkan.Albert Einstein (Tanudjaja 2011: 71) mengatakan, menciptakan suasana belajar yang kreatif dan menyenangkan adalah seni tinggi yang luar biasa dari suatu pengajaran.

Peningkatan terhadap hasil belajar siswa pada siklus II dikatakan berhasil,karena hal-hal yang menjadi refleksi dalam proses pembelajaran bagi guru dan siswa telah diperbaiki guru. Peneliti, guru serta para observer memutuskan untuk tidak dilanjutkan pada siklus berikutnya. Hal ini menunjukkan bahwa hipotesis telah tercapai yaitu menggunakan model Quantum
Teaching hasil belajar materi perbandingan pada siswa kelas $\mathrm{VII}_{9}$ SMP $\mathrm{N} 6$ Ambon dapat ditingkatkan.

\section{Kesimpulan}

Berdasarkan hasil dan pembahasan maka dapat disimpulkan bahwa profil hasil belajar siswa kelas $\mathrm{VII}_{9}$ SMP Negeri 6 Ambon dengan menggunakan model Quantum Teaching pada materi perbandingan, yaitu pada siklus I, terdapat 7 siswa $(24,13 \%)$ tuntas dan 22 siswa $(75,87 \%)$ belum tuntas. Selanjutnya pada siklus II, terdapat 23 siswa $(79,31 \%)$ tuntas dan 6 siswa $(20,68 \%)$.

\section{Daftar Pustaka}

De Porter., dkk. 2001.Quantum Teaching. Bandung: Kaifa.

----------------, 2011.Quantum Teaching. Bandung: Kaifa.

Herdian. 2009. Artikel PembelajaranQuantum, diaksespadatanggal 29 September 2012.

Joyce B., dkk. 2011.Models of Teaching, $8^{\text {th }}$ Edition. Jakarta: Insan

Mataheru, W. 2008. Analisis Proses Kognitif Siswa SD Dalam Pemecahan Masalah Matematika Ditinjau Dari Perbedaan Kemampuan. Buletin Pendidikan Matematika No.1 Vol 10, Maret 2008, Ambon: Program Studi Pendidikan Matematika Universitas Pattimura.

Miftahul. A. 2010. Quantum Teaching. Jogjakarta: Diva Press.

Ratumanan, T. G. 2004. Belajar dan Pembelajaran, Surabaya: Unesa University Press

Sanjaya, W. 2010. Strategi Pembelajaran Berorientasi Standar Proses Pendidikan. Jakarta: Kencana

-----------------. 2011. Perencanaan dan Desain Sistem Pembelajaran. Jakarta: Kencana.

Sudjana, N. 2002. Penilaian Hasil Dan Proses Belajar Mengajar. Bandung. Remaja Rosdakarya

Suryosubroto. 2002. Proses BelajarMengajar. Jakarta. Tanudjaja, M, 2011. Aku Cerdas Karena Tidak Bisa Matematika. Jakarta: Pt. Gramedia Pustaka Utama.

Yamin, 2010.Strategi Pembelajaran Berbasis Kompetensi. Jakarta: Press. 
